\title{
Overweight and stroke in the Whitehall Study
}

\author{
Roger Shinton, Martin Shipley, Geoffrey Rose
}

\begin{abstract}
Study objective-The aim was to examine the risk of increasing overweight for death from stroke.
\end{abstract}

Design-This was a prospective cohort study, in which the main outcome measure was the mortality ratio for stroke with increasing body mass index.

Setting-Civil service departments, Whitehall, London.

Subjects-Participants were 17753 men aged 40 to 64 years.

Measurements and main results-208 stroke deaths were recorded. Men aged 40 to 54 in the most overweight quintile of body mass index had a mortality ratio of 2.01 (95\% confidence interval 0.9 to 4.7$)$ compared to the thinnest quintile. The mortality ratio was $1.19(95 \%$ CI 0.7 to $2 \cdot 0)$ in men aged 55 to 64 . The increase in risk was more apparent in non-smokers: age adjusted mortality ratio $2.58(95 \%$ CI 1.2 to $5 \cdot 7)$. When smoking status and overweight were considered in combination a gradient of the age adjusted mortality ratio was observed, from 1.0 in thinner/non-smokers up to $3 \cdot 15$ in fatter/current smokers. On the assumption that smoking and obesity cause strokes, an estimated $60 \%$ of strokes could be prevented if these two easily identifiable risk factors could be avoided.

Conclusions - The risks of overweight for death from stroke were more apparent in younger subjects and non-smokers. A substantial proportion of stroke deaths occurring under the age of 80 years would probably be prevented if cigarette smoking and overweight could be avoided.

Medicine, University

of Birmingham,

Dudley Road

Hospital,

Birmingham

B18 7QH,

United Kingdom

R Shinton

Department of

Epidemiology and

Population Sciences,

London School of

Hygiene and Tropical

Medicine, Keppel St,

London WC1

M Shipley

G Rose

Correspondence to: Dr Shinton at 24 Belle Vue Terrace, Hampton-inArden, Solihull, West Midlands B92 0AR, UK

Accepted for publication July 1990 overweight itself, adjustment for variables which are also likely mechanisms (for example, hypertension) may be misleading. ${ }^{6}$ Some doubt, furthermore, has recently been cast on the interpretation of the results of statistical models which do not reflect the biological interactions of the risk factors under consideration. ${ }^{78}$ For these reasons an analysis avoiding both inappropriate adjustments and statistical modelling seemed worthwhile. The study will, however, take account of cigarette smoking, both because of its complex relation to obesity and stroke, ${ }^{9}$ and because overweight and cigarette smoking are particularly relevant to intervention since they can be easily identified without reference to medical practitioners.

The straightforward analysis of risk factors in clusters does require large case numbers. The cohort of Whitehall civil servants ${ }^{10}$ now enables assessment of the risk of overweight and its relationship to cigarette smoking for a substantial number of stroke deaths.

\section{Methods}

Details of the Whitehall study have been published $^{510}$; 18403 male civil servants aged 40-64 years were examined between 1967 and 1969 and their records flagged at the National Health Service Central Registry.

A self administered questionnaire, completed at the screening examination, included details of cigarette smoking. For the present analysis subjects were divided into non-smokers, excigarette smokers, current cigarette smokers, and others (non-responders; pipe or cigar smokers). The latter group was excluded, leaving a total of 17753 men on which to base this analysis. Subjects were weighed in light clothing and had their height measured with their shoes removed. Body mass index (weight in $\mathrm{kg} \div$ [height in metres] $]^{2}$ ) was grouped into quintiles. ${ }^{5}$

Mortality data were available until 31st January 1985, providing a minimum of 15 years of follow up. Total person-years at risk during the follow up period were cross tabulated by smoking status, body mass index quintile, and five year age group. Stroke deaths were defined as those where stroke (International Classification of Diseases, 8th Revision, 430-438) was certified as the underlying cause. This included cerebral infarct and thrombosis, cerebral and subarachnoid haemorrhage, and stroke of uncertain pathology.

Narrow age strata, each with sufficient case numbers, are ideally required to examine the possible confounding or interaction of age on the relation between overweight and stroke. The data were, therefore, stratified into two age groups (40-54 and 55-64 years) for presentation. 
Confidence intervals for unadjusted rate ratios were obtained by first calculating the confidence interval for the ratio of the stroke deaths using the binomial distribution and then dividing these by the ratio of the person-years. Age adjusted rate ratios were calculated as the ratio of directly standardised rates. These age standardised rates were obtained using the total Whitehall study population as standard. Confidence intervals for these adjusted rate ratios were calculated. ${ }^{11}$ Attributable risks were calculated by first estimating the expected strokes in each of two age groups (40-54 and 55-64 years) if the baseline rates had applied to the whole group; the difference between the expected and observed numbers estimates the avoidable stroke deaths in each age group. These were then added together.

\section{Results}

After 15 years of follow up 3427 men had died. Two hundred and eight deaths $(6 \cdot 1 \%)$ were attributed to stroke and $1352(39.5 \%)$ to coronary heart disease. A further seven strokes were in the pipe/cigar/non-responder group. Of the 208 stroke deaths, 26 were attributed to subarachnoid haemorrhage (ICD 430) and 42 to intracerebral haemorrhage (ICD 431).

At screening $43 \%$ (7601) of the men were current smokers, 38\% (6697) ex-smokers, and $19 \%$ (3455) had never smoked.

The variation in mortality rates by quintile of body mass index in the two age groups is shown in fig 1 . Table I provides the mortality rate ratios relative to the thinnest quintile and suggests there may be differences between the two age groups. However, mortality ratios for all ages have been presented both with and without age adjustment. Failure to adjust for age could overestimate the risks of overweight as there is a small rise in body mass index with age- $19 \%$ of men aged $40-54$ years were in the highest quintile of body mass index compared to $22 \%$ of men aged 55-64 years. Conversely, age adjustment could obscure risks if part of the added risk of advancing age is due to the increasingly long exposure to being overweight. The data suggest a steady rise in the hazards of overweight in men under 55 years but a $\mathrm{U}$ shaped curve in the older age group. Overall, obesity appears to carry increased risk of stroke.

The age adjusted stroke mortality rate ratio for ex-smokers compared with non-smokers was 1.25
(95\% CI 0.8 to 2.0 ), while that for current smokers was 1.66 (95\% CI 1.1 to 2.6 ).

Because smokers are at increased risk of stroke and also tend to be thinner, the risk of overweight for death from stroke was examined in the different smoking categories. Figure 2 and table II suggest that the risk gradient (but not the actual rate) is greater in those who never smoked. Confidence intervals, however, are wide.

In order to assess the risks for death from stroke of different overweight/smoking status combinations, the lower two and upper three quintiles of body mass index were each grouped together. As age is associated with both stroke risk

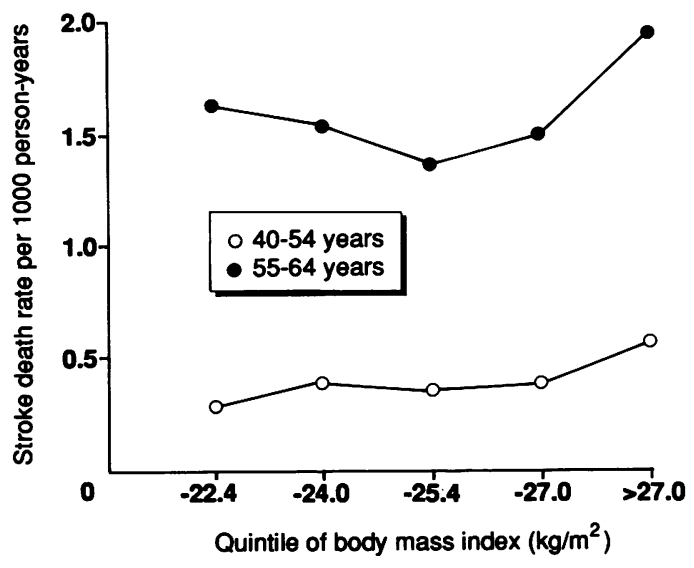

Figure 1 Stroke mortality rate by quintile of body mass index in men aged 40 to 54 years and 55 to 64 years.

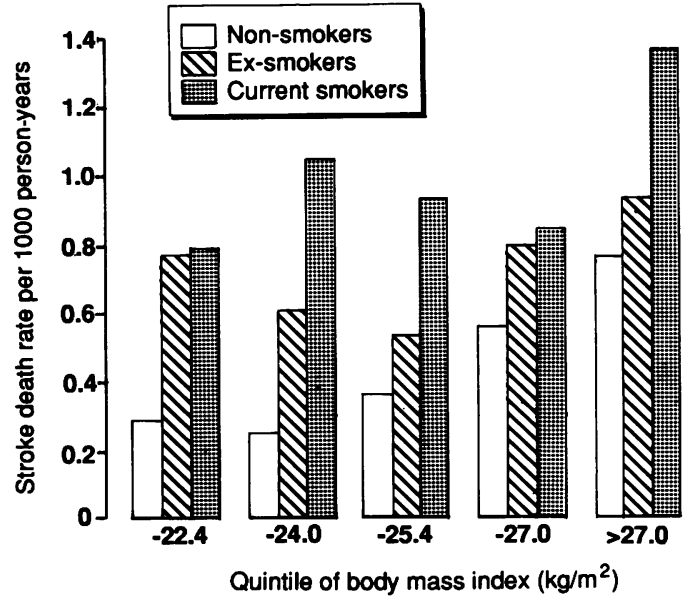

Figure 2 Stroke mortality rate by quintile of body mass index in the different smoking status groups.
Table I Stroke mortality rate ratio by quintile of body mass index

\begin{tabular}{|c|c|c|c|c|c|}
\hline & \multicolumn{5}{|c|}{ Body mass index quintile $\left(\mathrm{kg} / \mathrm{m}^{2}\right)$} \\
\hline & $-22 \cdot 4$ & $-24 \cdot 0$ & -25.4 & $-27 \cdot 0$ & $>27.0$ \\
\hline $\begin{array}{l}\text { Person-years at risk } \\
\text { No of stroke deaths } \\
\text { Rate ratio } \\
(95 \% \text { confidence interval) }\end{array}$ & $\begin{array}{c}39048 \\
11 \\
(1 \cdot 0)\end{array}$ & $\begin{array}{r}37265 \\
14 \\
1.33\end{array}$ & $\begin{array}{c}40-54 \text { Years } \\
37436 \\
13 \\
1.23\end{array}$ & $\begin{array}{c}33371 \\
13 \\
1 \cdot 38\end{array}$ & $\begin{array}{c}33578 \\
19 \\
2 \cdot 01 \\
(0 \cdot 9 \text { to } 4 \cdot 7)\end{array}$ \\
\hline $\begin{array}{l}\text { Person-years at risk } \\
\text { No of stroke deaths } \\
\text { Rate ratio } \\
\text { ( } 95 \% \text { confidence interval) }\end{array}$ & $\begin{array}{c}17127 \\
28 \\
(1 \cdot 0)\end{array}$ & $\begin{array}{r}15629 \\
24 \\
0.94\end{array}$ & $\begin{array}{c}55-64 \text { Years } \\
16874 \\
23 \\
0 \cdot 83\end{array}$ & $\begin{array}{c}17404 \\
26 \\
0.91\end{array}$ & $\begin{array}{c}18984 \\
37 \\
1 \cdot 19 \\
(0 \cdot 7 \text { to } 2 \cdot 0)\end{array}$ \\
\hline $\begin{array}{l}\text { Person-years at risk } \\
\text { No of stroke deaths } \\
\text { Rate ratio } \\
\text { ( } 95 \% \text { confidence interval) } \\
\text { Age adjusted rate ratio } \\
(95 \% \text { confidence interval) }\end{array}$ & $\begin{array}{l}56175 \\
39 \\
(1 \cdot 0) \\
(1 \cdot 0)\end{array}$ & $\begin{array}{r}52894 \\
38 \\
1.03\end{array}$ & $\begin{array}{c}\text { All ages } \\
54310 \\
36 \\
0.95\end{array}$ & $\begin{array}{r}50775 \\
39 \\
1 \cdot 11\end{array}$ & $\begin{array}{c}52562 \\
56 \\
1 \cdot 53 \\
(1 \cdot 0 \text { to } 2 \cdot 4) \\
1 \cdot 30 \\
(0 \cdot 9 \text { to } 2 \cdot 0)\end{array}$ \\
\hline
\end{tabular}


Table II Stroke and all cause mortality rate ratios by quintile of body mass index in separate smoking status groups
Table III Stroke mortality rate and rate ratios (thin/non-smokers as baseline), stratified by age group, body mass index and smoking status and smoking status, the results have been presented in two age groups and, as the rate ratios were generally consistent in the different age strata, after age adjustment (table III). Although numbers are small, the results suggest that overweight is more of a risk in the older age group among non-smokers. The principal conclusion, however, on examining the overall rate ratios in different combinations, is that there is an increased risk in all except the thinner nonsmokers. The rate ratio rises to $3 \cdot 15$ in the more obese current smokers

The attributable risk of a combination of both cigarettes and/or excess weight was calculated (table IV). On the assumption that cigarette smoking and overweight directly cause strokes and that the stroke death rates reported are valid around $60 \%$ of stroke deaths may be prevented if cigarettes and excess weight could be avoided. For cigarette smoking alone (ex- and current) the attributable risk was $30 \%$. The prevention of stroke by the avoidance of cigarettes and overweight is consistent with a reduction in the all cause mortality rate (table II).

\section{Discussion}

These results support the view that overweight increases the risk of stroke. This conclusion is no surprising in view of the strong link between

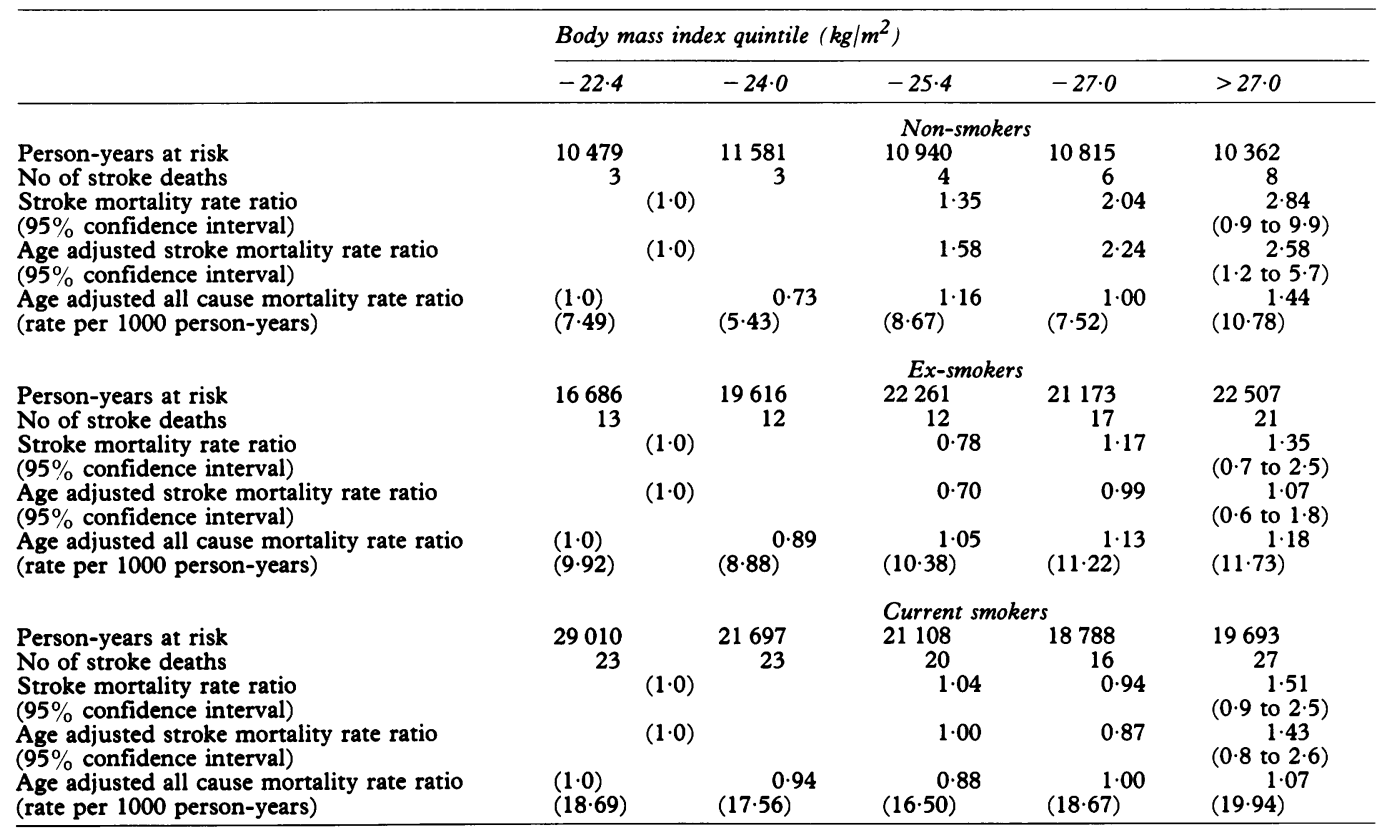

\begin{tabular}{|c|c|c|c|c|c|c|}
\hline & \multicolumn{6}{|c|}{ Body mass index $\left(\mathrm{kg} / \mathrm{m}^{2}\right)$} \\
\hline & \multicolumn{2}{|c|}{ Non-smoker } & \multicolumn{2}{|l|}{ Ex-smoker } & \multicolumn{2}{|c|}{ Current smoker } \\
\hline & $-24 \cdot 0$ & $>24 \cdot 0$ & $-24 \cdot 0$ & $>24.0$ & $-24 \cdot 0$ & $>24 \cdot 0$ \\
\hline $\begin{array}{l}\text { Person-years at risk } \\
\text { No of stroke deaths } \\
\text { Rate } / 10000 \text { person-years } \\
\text { Rate ratio } \\
\text { ( } 95 \% \text { confidence interval) }\end{array}$ & $\begin{array}{l}17411 \\
3 \\
\quad 1 \cdot 72 \\
(1 \cdot 0)^{1 \cdot 72}\end{array}$ & $\begin{array}{l}23532 \\
2 \\
0.85 \\
0.49\end{array}$ & $\begin{array}{c}25101 \\
8 \\
3 \cdot 19 \\
1.85\end{array}$ & $\begin{array}{c}4 \text { Years } \\
42484 \\
15 \\
3.53 \\
2.05\end{array}$ & $\begin{aligned} 33801 \\
14 \\
4 \cdot 14 \\
2 \cdot 41\end{aligned}$ & $\begin{array}{c}38368 \\
28 \\
7 \cdot 30 \\
4 \cdot 24 \\
(1 \cdot 3 \text { to } 22)\end{array}$ \\
\hline $\begin{array}{l}\text { Person-years at risk } \\
\text { No of stroke deaths } \\
\text { Rate } / 10000 \text { person-years } \\
\text { Rate ratio } \\
(95 \% \text { confidence interval) }\end{array}$ & $\begin{array}{l}4650 \\
3 \\
(1 \cdot 0)^{6.45}\end{array}$ & $\begin{array}{l}8584 \\
16 \\
18 \cdot 64 \\
2 \cdot 89\end{array}$ & $\begin{array}{c}11201 \\
17 \\
15 \cdot 18 \\
2 \cdot 35\end{array}$ & $\begin{array}{c}4 \text { Years } \\
23457 \\
35 \\
14.92 \\
2.31\end{array}$ & $\begin{array}{r}16906 \\
32 \\
18.93 \\
2.93\end{array}$ & $\begin{array}{c}21221 \\
35 \\
16.49 \\
2 \cdot 56 \\
(0 \cdot 8 \text { to } 13)\end{array}$ \\
\hline $\begin{array}{l}\text { Person-years at risk } \\
\text { No of stroke deaths } \\
\text { Rate ratio } \\
(95 \% \text { confidence interval) }\end{array}$ & $\begin{array}{c}22061 \\
6 \\
(1 \cdot 0)\end{array}$ & $\begin{array}{c}32116 \\
18 \\
2 \cdot 20 \\
(0 \cdot 8 \text { to } 5 \cdot 7) \\
\end{array}$ & $\begin{array}{c}\text { All ages } \\
36302 \\
25 \\
2 \cdot 40 \\
(1 \cdot 0 \text { to } 6 \cdot 0)\end{array}$ & $\begin{array}{c}\text { age adjusted) } \\
65941 \\
50 \\
2 \cdot 24 \\
(0.9 \text { to } 5 \cdot 4) \\
\end{array}$ & $\begin{array}{c}50707 \\
46 \\
2 \cdot 43 \\
(1 \cdot 0 \text { to } 5 \cdot 8)\end{array}$ & $\begin{array}{c}59589 \\
63 \\
3 \cdot 15 \\
(1 \cdot 3 \text { to } 7 \cdot 5) \\
\end{array}$ \\
\hline
\end{tabular}

Table IV Attributable risk for stroke of a combination of cigarette smoking and excess weight

\begin{tabular}{llcc}
\hline & $\begin{array}{l}\text { Expected deaths } \\
\text { based on rate } \\
\text { of non-smokers } \\
\text { with body mass } \\
\text { index }<24.0 \mathrm{~kg} / \mathrm{m}^{2}\end{array}$ & Observed deaths & $\begin{array}{l}\text { Attributable } \\
\text { stroke deaths } \\
\text { (percent) }\end{array}$ \\
\hline $40-54$ & 31 & 70 & 39 \\
$55-64$ & 55 & 138 & $(56)$ \\
Total & 86 & 208 & 83 \\
& & & $(60)$ \\
& & & $(59)$ \\
\hline
\end{tabular}

overweight and blood pressure. ${ }^{12}$ The hazards of overweight, furthermore, are more apparent when either younger age groups or non-smokers are examined separately.

The finding that the risks of overweight are more obvious at a younger age was also reported in the Framingham cohort. ${ }^{4}$ Other stroke studies of adequate power in which stroke cases have been predominantly under the age of 70 have all indicated that overweight is a risk factor for stroke. ${ }^{13-17}$ The risk, however, has not been 
apparent in stroke studies in which the events have predominantly occurred over the age of $70 .{ }^{18-21}$ There appears to be a consistent pattern of a reduction in the increased risk of overweight for stroke as age advances. Whether this is also true for non-smokers is not yet clear.

The U shaped curve for body mass index and the risk of stroke in the older age group of this cohort appears to be due to the influence of thin long term smokers. It is noteworthy that in non-smokers the increasing risks of overweight are more apparent in the older age group. An explanation for this could be that the dangers of overweight do not become manifest early in non-smokers because the additional vascular damage caused by smoking is absent.

The results suggest that the danger may be relatively greater in non-smokers (although the absolute excess is less). The explanation for this is probably that smokers, and particularly heavy smokers, are both thinner and at increased risk of stroke compared to non-smokers. This complication is not a problem when examining the non-smokers, although the small number of stroke deaths in this group (24) means that confidence intervals are wide. The varying rate ratios in the different smoking groups suggests that adjusting the risks of overweight for smoking status could obscure real effects, particularly in non-smokers. An overall smoking adjusted ratio would probably only be relevant to other populations with a similar proportion of smokers or ex-smokers. Fortunately these are now rare. For this reason smoking adjusted rate ratios have not been presented. These findings could explain why previous studies have shown a clearer risk of overweight for stroke in women (who tended not to smoke) than in men. 4

Not all previous studies in younger populations have indicated overweight is a risk factor for stroke. In some this may have been because the investigation was too small. ${ }^{22} 23$ In others, multiple adjustments for possible confounding variables are hard to interpret. ${ }^{24}$ If, as is likely, overweight is causally linked to high blood pressure, diabetes, and hypercholesterolaemia, then adjustment for these variables could obscure the real risk of overweight itself. These variables may actually be the mechanisms through which obesity causes strokes.

Many cohort and case-control studies do indeed positively associate obesity or overweight with stroke. ${ }^{13-17} 25-28$ The association is likely to be causal, as consideration of other risk factors as possible confounding variables fails to provide an alternative explanation. In the Whitehall cohort the risk is apparent in individual age strata and alters little following age adjustment. Cigarette smoking does appear to interact with, but not to confound, the association as the risks of overweight are clearest in non-smokers. Both excessive alcohol consumption and physical inactivity are possible but currently uncertain risk factors for stroke. ${ }^{1}$

The evidence that smokers and ex-smokers are at increased risk of stroke is strong, ${ }^{29}$ and is supported by our findings. Examining the risk of combinations of smoking and overweight was considered particularly worthwhile because both are risk factors easily understood and recognisable by the whole population, and over which individuals potentially have control. In this cohort the risk of differing smoking/obesity combinations rises steadily from thin/nonsmokers to overweight/current smokers. In a cohort of college students Paffenbarger and Wing found similar results: a stroke morbidity ratio of $2 \cdot 6$ among smoking/obese students compared with their non-smoking/thin colleagues. ${ }^{13}$

Only six of the 208 stroke deaths occurred in people who were relatively thin and claimed to have never smoked. There was a similar finding in a large cohort study of nurses, where only eight of 274 strokes occurred among non-smokers in the thinnest of three body mass index groups. ${ }^{30}$

The attributable (excess) risk of around $60 \%$ suggested by these results implies a considerable potential for stroke prevention. Indeed, any misclassification of true smoking status or total body fat will have tended to underestimate the attributable risk. There is a suggestion that measuring body fat by subscapular skinfold thickness or waist/hip ratio predicts more accurately the risks of stroke. ${ }^{1727}$

Although there are advantages in the analysis of data in specific subgroups, there remains the disadvantage of small case numbers in any given group. To confirm some of the findings outlined above, further studies limited to specific subgroups, for example persons who have never smoked, will be required.

We wish to thank Mrs Dilys Thomas for preparation of the figures. RAS was supported by the Wellcome Trust.

1 Dyken ML, Wolf PA, Barnett HJM, et al. Risk factors in stroke: a statement for physicians by the sub-committee on
risk factors and stroke of the stroke council. Stroke 1984; 15: 1105-11.

2 Warlow CP. Cerebrovascular disease. In: Weatherall DJ, Ledingham JGG, Warrell DA, eds. Oxford textbook of medicine. Oxford: Oxford University Press, 1987: 21.155.

3 Ostfeld AM. A review of stroke epidemiology. Epidemiol Rev 1980; 2: 136-52.

4 Hubert HB, Feinleib M, McNamara PM, Castelli WP. Obesity as an independent risk factor for cardiovascular disease: a 26-year follow up of participants in the Framingham heart study. Circulation 1983; 67: 968-77.

5 Fuller JH, Shipley MJ, Rose G, Jarrett RS, Keen H. Mortality from coronary heart disease and stroke in relation to degree of glycaemia: the Whitehall Study. $B M \mathcal{F} 1983$; 287: 867-70.

6 Rothman KJ. Modern epidemiology. New York: Little Brown, 1987.

Vandenbroucke JP. Should we abandon statistical modelling altogether? Am F Epidemiol 1987; 126: 10-13.

8 Lee J. An insight on the use of multiple logistic regression analysis to estimate association between risk factor and disease occurrence. Int F Epidemiol 1986; 15: 22-29.

9 Shinton R, Beevers G. Meta-analysis of the relation between cigarette smoking and stroke. BMF 1989; 298: 789-94.

10 Reid DD, Brett GZ, Hamilton PJS, Jarrett RJ, Keen H, Rose G. Cardiorespiratory disease and diabetes among middle aged male civil servants: A study of screening and intervention. Lancet 1974; i: 469-73.

11 Bŕeslow NE, Day NE. Statistical methods in cancer research. Vol II. The design and analysis of cohort studies. IARC
Scientific Publications No 82. Lyon: International Agency for Research on Cancer, 1987.

12 Intersalt cooperative research group. Intersalt: an international study of electrolyte excretion and blood pressure. Results for 24 hour urinary sodium and potassium excretion. BMf 1988; 297: 319-28.

13 Paffenbarger RS, Wing AL. Chronic disease in former college students: early precursors of non-fatal stroke. $A m \mathcal{F}$ Epidemiol 1971; 94: 524-30.

14 Paffenbarger RS, Wing AL. Characteristics in youth predisposing to fatal stroke in later years. Lancet 1967; $\mathrm{i}$ :

15 Herman B, Leyton ACM, Van Luisk JH, Franken CWGM, Opdecoul AAW, Schulte BPM. An evaluation of risk factors for stroke in a Dutch community. Stroke 1982; 13:

6 Rhoads GG, Kagan A. The relation of coronary heart disease, stroke, and mortality to weight in youth and middle age. Lancet 1983; i: 492-5. 
17 Welin L, Svardsudd K, Wilhelmsen L, Larsson B, Tibblin $\mathrm{G}$. Analysis of risk factors for stroke in a cohort of men born in 1913 . $N$ Engl $f$ Med 1987; 317: 521-6.

18 Tanaka H, Veda Y, Hayashi M, et al. Risk factors for cerebral haemorrhage and cerebral infarction in a Japanese rural community. Stroke 1982; 13: 62-73.

19 Aronow WS, Starling L, Etienne F, et al. Risk factors for atherothrombotic brain infarction in persons over 62 years of age in a long-term health care facility. $\mathcal{f} \mathrm{Am}$ Geriatr Soc 1987; 35: 1-3.

20 Paganini-Hill A, Ross RK, Henderson BE. Postmenopausal oestrogen treatment and stroke: a prospective study. $B M \mathcal{F}$ 1988; 297: 519-22.

21 Khaw KT, Barrett-Connor E, Suarez L, Criqui M. Predictors of stroke associated mortality in the elderly. Stroke 1984; 15: 244-48.

22 Pettiti DB, Wingerd J, Pellegrin F, Ramcharan S. Risk of vascular disease in women: smoking, oral contraceptives, noncontraceptive estrogens, and other factors. $\mathfrak{f} A M A$ 1979; 242: 1150-4.

23 Semenciw RM, Morrison HI, Mao Y, et al. Major risk factors for cardiovascular disease mortality in adults: results from the Nutrition Canada Survey cohort. Int $¥$ Epidemiol 1988; 17: 317-23.
24 Medical research council working party. Stroke and coronary heart disease in mild hypertension: risk factors
and the value of treatment. $B M \mathcal{F}$ 1988; 296: $1565-70$.

25 Abu-Zeid HAH, Choi NW, Maini KK, Hsu P-M, Nelson NA. Relative role of factors associated with cerebral infarction and cerebral haemorrhage. A matched pai

26 Ostfeld AM, Shekelle RB, Klawans H, Tufo HM. Epidemiology of stroke in an elderly welfare population. Am $₹$ Public Health 1974; 64: 450-8.

27 Lapidus L, Bengtsson C, Larsson BO, Pennert K, Nybo E Sjostrom L. Distribution of adipose tissue and risk of cardiovascular disease and death: a 12 year follow up of participants in the population study of women in Gothenburg, Sweden. BMF 1984; 289: 1257-61.

28 Heyden S, Hames CG, Bartel A, Cassel JC, Tyroler HA Cornoni JC. Weight and weight history in relation to cerebrovascular and ischaemic heart disease. Arch Intern Med 1971; 128: 956-60.

29 Donnan GA, Adena MA, O'Malley HM, McNeil JJ, Doyle AE, Neill GC. Smoking as a risk factor for cerebral AE, Neill GC. Smoking as a risk factor for cerebra
ischaemia. Lancet 1989; ii: $643-47$. 30 Colditz $G$ L Bonita $R$, Stampfer

smoking and risk of stroke in middle-aged women. NEnglf Med 1988; 318: 937-41. 